\title{
Relief operations as a multi-project: Colombian case
}

\section{María Catalina González Forero ${ }^{a}$ and Leonardo José González Rodríguez ${ }^{\text {* }}$}

${ }^{a}$ Grupo de investigación en Alimentación, Gestión de Procesos y Servicio, Escuela Internacional de Ciencias Económicas y Administrativas, Universidad de La Sabana, Km 7 autopista norte de Bogotá, D.C., Chía (Cundinamarca), Colombia ${ }^{b}$ Grupo de investigación en Sistemas Logísticos, Facultad de Ingeniería, Universidad de La Sabana, Km 7 autopista norte de Bogotá, D.C., Chía (Cundinamarca), Colombia

\section{CH RON I C L E}

\section{Article history:}

Received November 112018

Received in Revised Format

May 242019

Accepted May 242019

Available online

May 242019

Keywords:

Humanitarian logistics

Disaster relief operations

Project management

Colombia

\begin{abstract}
A B S T R A C T
The purpose of this paper is to present the relief operations (RO), responding to a sudden, natural, national disaster (SNND) as a multi-mode resource-constrain multi-project scheduling problem (MRCMPSP). A conceptual framework at a strategic level is constructed and the Colombian RO for an earthquake response is shown as an illustrative case. We concluded that RO can be addressed as a MRCMPSP and that for Colombian case, it is a convenient way to board it. Addressing RO as a MRCMPSP allows managers to implement different project scheduling tools successful in other contexts.
\end{abstract}

(C) 2020 by the authors; licensee Growing Science, Canada

\section{Introduction}

Humanitarian logistics is an umbrella term for a mixed array of operations. It covers disaster relief (immediate operations after the disaster occurs) as well as continuous support for developing affected regions (Kovács \& Spens, 2007). Disaster Relief Operations (RO) require significant amounts of rescue materials that must be assigned and distributed in a short period of time (Ferrer et al., 2015; Guanxiang et al., 2010; Nappi \& Souza, 2015; Oloruntoba \& Gray, 2006). They are concerned with managing the flow of those supplies and personnel from their point of origin to the appropriate places at the correct time, with the purpose of alleviating the suffering of affected people (Holguín-Veras et al., 2012b).

It has been demonstrated that there is a direct relationship between the number of deaths after a SNND and logistics management strategies used for disaster response (Moreno, 2012). For example, because of absence of anti-seismic standards, and as a result of weak logistics management, it was estimated that over 300,000 people died in the Haitian earthquake of 2010 (Haiti, Government, 2010), in contrast to 521 victims in the Chilean earthquake in 2010 (Elnashai, 2012). This significant difference in the number

* Corresponding author Tel. : +57-1-8615555

E-mail: leonardo.gonzalez1@unisabana.edu.co (L.J. González Rodríguez)

2020 Growing Science Ltd.

doi: $10.5267 /$ j.ijiec.2019.5.002 
of deaths was observed despite the magnitude and duration of the Chile earthquake being higher by 1.5 (moment magnitude scale) and longer by $65 \mathrm{~s}$, respectively, than the Haiti earthquake. Therefore, in order to decrease the probability of human loss in an SNND, it is relevant to study logistics of RO. Furthermore, its study relevance increases, since logistics efforts account for 80 percent of disaster relief (Van Wassenhove, 2006; Ophiyandri et al., 2013).

Logistics for RO have been mainly addressed as a particular supply chain (Makepeace et al., 2017; Dufour et al., 2017; Sahebjamnia et al., 2017; Goldschmidt \& Kumar, 2016; D'Haene et al., 2015; Zheng et al., 2015; Ransikarbum \& Mason, 2014; Overstreet et al., 2011; Van Wassenhove \& Pedraza Martinez, 2012; Holguín-Veras et al. 2012b; Altay \& Green III, 2006; Van Wassenhove, 2006; Oloruntoba \& Gray, 2006; Brucker et al., 1999). In this study, we used the project management approach.

The Project Management Institute (PMI) defines project management as the "application of knowledge, skills, tools and techniques to project activities in order to meet or exceed stakeholder needs and expectations from a project" (PMI, 2004). Project Management has been studied in both Management Science and Operations Research. Management Science trends to focus on quantitative tools and the soft skills necessary to manage project successfully. Operations Research gives the essential scientific contribution to the success of project management through the development of models and algorithms (San Cristobal, 2016). In this paper, we focus on Operations Research approach of Project Management.

Project management has been widely used in many fields (architecture engineering, software development, and production manufacture). In the literature reviewed we found that project management for humanitarian logistics has been boarded mainly for recovery programs (not immediate response projects) and through non-Operations Research models, but Management Science scope such as: leadership and community participation (Mojtahedi and Oo, 2017; Lin et al., 2016; Sadiqi et al., 2016), housing projects (Vahanvati \& Mulligan, 2017; Dikmen \& Elias-Ozkan, 2016) analysis of project's performance (Kim \& Choi, 2013; Lin Moe et al., 2007), resource availability (Chang et al., 2012), and others (Kalkman \& de Waard, 2017; Gacasan \& Wiggins, 2017).

According to the Operations Research approach of Project Management, the life cycle of a project consists of six phases (Demeulemeester \& Herroelen, 2002): (1) a conceptual design phase where the needs that justify project execution are identified. A (2) project definition phase in which the objectives of the project are defined along with the scope and strategy to achieve these objectives. (3) The planning phase which involves identifying the activities to be carried out in order to achieve the project objective such as activity durations, precedence relations between them, and resources needs and availability are estimated. Subsequently, the project enters the (4) scheduling phase that includes the construction of a schedule that identifies the start and end times of each of the activities, and the allocation of resources. During the (5) execution phase of the project, its progress must be monitored, applying corrective actions if necessary (control). Finally, the project enters the (6) termination phase, which involves the delivery of project outputs (products and/or services) and the writing of performance reports. Patanakul et al. (2010) present an empirical study on the use of project management tools and techniques across project life-cycle and according to nine knowledge area: integration management, scope management, cost management, quality management, time management, risk management, human talent management, communications management and procurement management. For example, the CPM (critical path method), PERT (Program evaluation and review technique), GERT (Graphical Evaluation and Review Technique), Gantt charts, simulation, Monte Carlo analysis, buffer management, schedule crashing, milestone charts and variance analysis are the main techniques for project's time management.

In this document, we focus on the (3) planning phase of a project, with the intention to prepare the (4) scheduling phase. A Project Scheduling Problem (PSP) is visually represented in two ways. One of them is the acyclic graph $G=(N, A)$ which contains a set of $N$ nodes and a set of $A$ arcs (see an example project 
in Figure 1). The nodes represent project activities, and the arcs represent the beginning and end of the precedence relationships. In the project representation example of Figure 1, each activity is identified by a number in the center of the node. Activities 1 and 9 are dummy activities because they don't consume any time or resources; they just indicate, respectively, the start and end of the project. Each arc $(i, j) \in A$, indicates that activity $i,(i=1, \ldots, n)$ is an immediate predecessor of activity $j$. It means that the activity $j$ can't begin while activity $i$ hasn't finish. The duration time $(d i)$ of the activity is shown below each node, and the resource needed to be execute is shown above each node. In the example of Figure 1, only one resource type is considered and its total availability is five (5) units. Projects visual representations helps to identify its critical path(s). Projects have at least one critical path, which is the path from the starting to the finish node with the highest duration time. Activities that belong to the critical path are considered urgent activities to execute because if even one creates a delay it represents a delay of the whole project.

\section{Total Resource Availability $=5$}

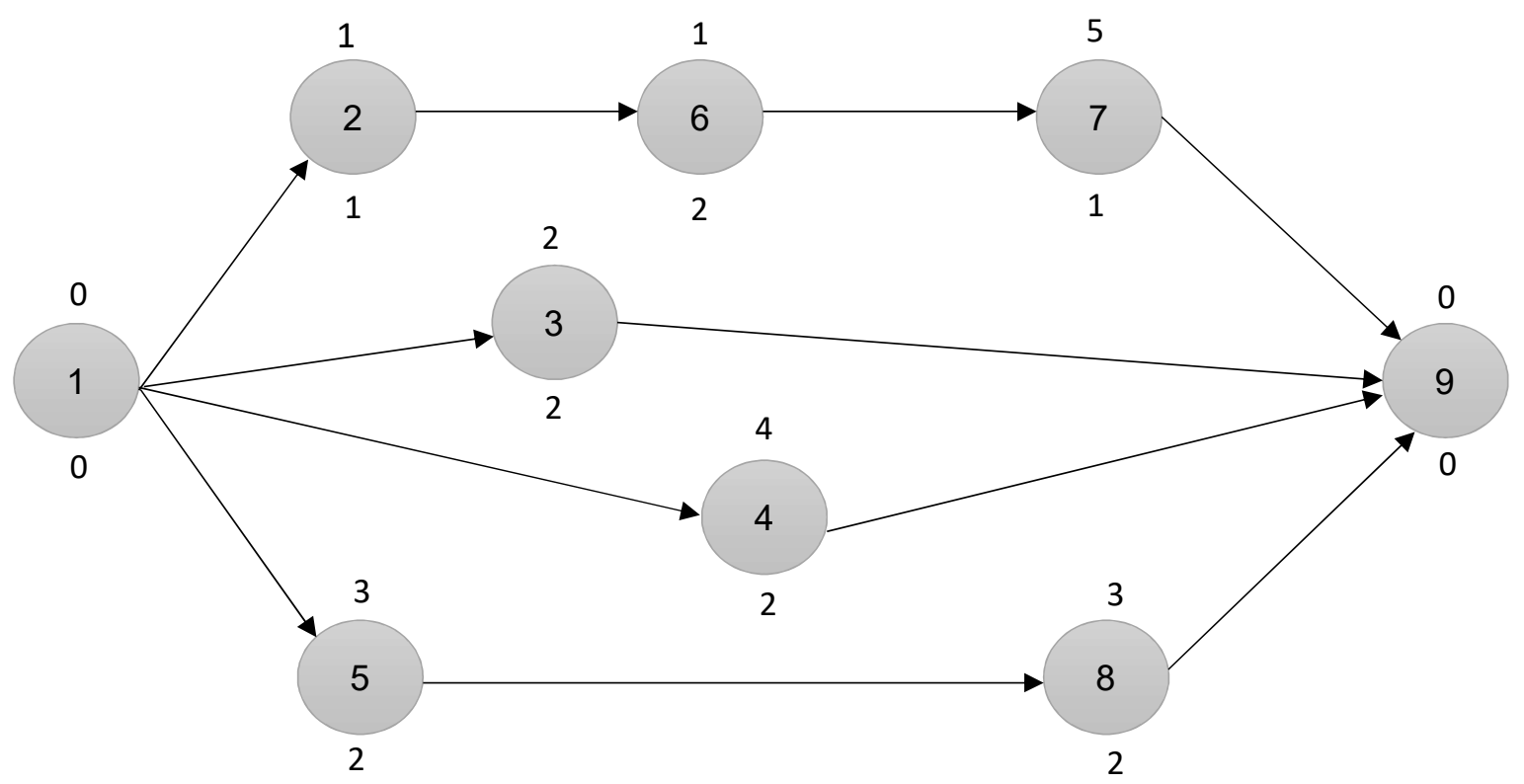

Fig. 1. Nine-activity project representation example. Source: Based on Demeulemeester and Herroelen, 200

Project scheduling deals with decision-making on determining the time required to implement the activities of a project to achieve a certain objective and the allocation of resources for each activity (San Cristobal, 2016). Among different factors, correct scheduling is one of the vital elements for project management success; incorrect scheduling can considerably increase the project costs (Habibi et al., 2018). There are several ways to schedule projects including the Critical Path Method (CPM) and Program Evaluation and Review Technique (PERT). Various methods such as resource leveling and allocation, network analysis methods, Gantt chart, mathematical methods and simulation have been use for solving project scheduling problems.

There is a lack of research in specialized literature that have presented a project scheduling for managing RO. In the literature reviewed, only two documents board RO as a scheduling project, but none of them sets a conceptual framework of the project definition and characteristics. Yan et al., (2009) proposed a heuristic model for solving the scheduling problem of a specific maritime disaster rescue project. Moreno (2012) presented the Colombian RO for a natural, sudden, and national disaster, aiming to find strategic policies that minimizes the number of death. 
Because of the importance of studying $\mathrm{RO}$ and the lack of research addressing the problem by employing a project scheduling approach, the objective of this paper is to present RO for SNND as a MRCMPSP. The Colombian RO are presented as an illustrative case.

The paper is organized as follows: Section 2 presents the conceptual frame of projects characteristics. Section 3 shows how RO can be managed as a project of the MRCMPSP type. Section 4 presents the Colombian RO case for an earthquake as a MRCMPSP, and analyzes its characteristics. Conclusions are presented in Section 5.

\section{Projects characteristics}

A project is defined as a "unique process, consisting of a set of coordinated and controlled activities with start and finish dates, undertaken to achieve an objective conforming to specific requirements, including the constraints of time, cost and resources" (ISO, 1990).

To solve project scheduling problems, project managers need to understand the characteristics of the project. Understanding projects characteristics is of significance importance for project managers because of differences associated with decisions making and goal attainment. Its characteristics affects the modelling, evaluation, and control of projects and the objectives of time, cost, quality and safety (San Cristobal, 2017). For example, with projects that have been characterized as complex (network complexity), it has been demonstrated that network methods are efficient tools for solving scheduling problems (Habibi et al., 2018; Martinelli et al., 2016). In addition to the objective function, Browning and Yassine (2010a) define three characteristics of a project: network complexity $(C)$, resource distribution $(A R L F)$, and resource contention $(M A U F)$.

\subsection{Network Complexity (C)}

Measuring network complexity has become an integral part of project management (He et al., 2015; Lu et al., 2015), and generally measures the number of precedence relationships between activities. A greater number of precedence relationships among the activities leaves less flexibility for doing them at a different time (higher complexity).

In its most basic form, the measure of network complexity accounts for the number of activities or nodes, and precedence relationships or arcs. Browning and Yassine (2010b) suggested a [0,1] normalized network complexity measure, for a project with six or more activities, and have at least N-1 nonredundant arcs, as follows:

$$
C=\frac{4 A^{\prime}-4 N+4}{(N-2)^{2}}
$$

where $A^{\prime}$ is the number of non-redundant arcs, and $\mathrm{N}$ is the number of activities or nodes of the project. Based on the experiment conducted by Browning and Yassine (2010a), low complexity is defined for $C \leq 0.14$, medium complexity is defined for $0.14<C<0.69$, and high network complexity is defined for $C \geq 0.69$. In the case of multiple projects, network complexity for $L$ projects is defined as a vector $C=$ $\{C 1, C 2, C 3, \ldots C L\}$.

\subsection{Resource distribution (ARLF)}


This factor identifies whether the bulk of the total resources required by a project is in the front or back half of its (resource unconstrained) critical path (CP) duration (see Figure 2). ARLF is calculated using Eq. (2),

$$
A R L F_{l}=\frac{1}{C P_{l}} \sum_{t=1}^{C P_{l}} \sum_{k=1}^{K_{i l}} \sum_{i=1}^{N_{l}} Z_{i l t} X_{i l t}\left(\frac{r_{i l k}}{K_{i l}}\right)
$$

where

$C P_{l}$ is the critical path duration of project $l$,

$N_{l}$ is the number of activities of project $l$,

$K_{i l}$ is the number of resource types required by activity $i$ of project $l$,

$r_{i l k}$ is the amount of $\mathrm{k}$ resource type required by activity $i$ of project $l$,

$Z_{\text {ilt }}=\left\{\begin{array}{c}-1, \quad t \leq \frac{C P_{l}}{2} \\ 1, \quad t>\frac{C P_{l}}{2}\end{array}\right.$,

$X_{i t}=\left\{\begin{array}{l}1, \text { if activity } i \text { of project } l \text { is active at time } t \\ 0, \text { otherwise }\end{array}\right.$

$Z_{i l t} X_{i l t} \epsilon\{-1,0.1\}$.

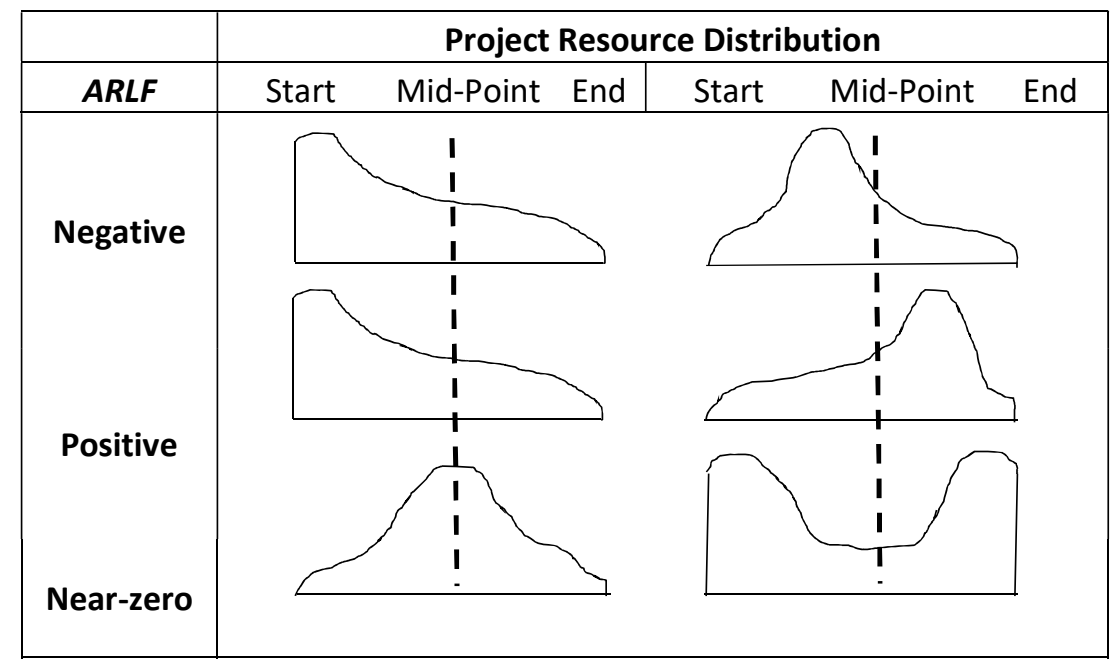

Fig. 2. Possible resource distribution. Source: Browning and Yassine, 2010a

Projects with $A R L F \approx 0$ can have dramatically different shapes. To address these issues, we adopt the normalized $A R L F(N A R L F)$ measure proposed by Browning and Yassine (2010a) which normalizes the resource distribution over the problem's CP duration:

$N A R L F=\frac{1}{L C P_{\operatorname{Max}}} \sum_{l=1}^{L} \sum_{t=1}^{C P l} \sum_{k=1}^{K_{i l}} \sum_{i=1}^{N l} Z_{i l t} X_{i l t}\left(\frac{r_{i l k}}{k_{i l}}\right)$

where

$C P_{\text {Max }}=\operatorname{Max}(C P 1, \ldots, C P L)$

\subsection{Resource contention (MAUF)}


Resource contention measure is used when resource distribution ( $A R L F)$ measure is not sufficient to describe the location of the bulk of the resources required. This case is represented by the last row in Figure $5(A R L F \approx 0)$, in which the distribution of resources can have different behaviors under one $A R L F$ value. For this case, Browning and Yassine (2010a) proposed a modified factor of average resource utilization (MAUF).

\section{Relief Operations as a MRCMPSP}

In this section, we build a conceptual framework showing, first, how RO is considered as a project. Then, we present the resource constrain scheduling model appropriated to be used for RO projects. Finally, the convenience to board the multimode and the multi-project models for RO projects is discussed.

\subsection{Relief Operations as a Project}

Conceptually, Demeulemeester and Herroelen (2002) (quoting Slack et al, 1998) claim that the diversity of projects (from the construction of a tunnel channel to planning a wedding) seems to have six common elements: an objective or goal, uniqueness, complexity, temporary nature, uncertainty, and life cycle. RO meet each of these features to be considered as a project, as described below.

An objective or goal: projects must have a definable product, result, or output that is typically defined in terms of cost, quality, and time required to complete project activities. Relief Operations projects have a definable product, result or output, which is the delivery of supplies and services to people affected by a disaster (Wassenhove, 2006). These deliveries might be done within constraint resources (minimum cost), attending affected people (quality), and the fastest deliveries (time) (Holguín-Veras et al., 2012b).

Uniqueness: a project is unique and not a repetitive business. Repeated similar projects have distinct differences in terms of the usage and availability of resources, and the actual environment where these projects are executed. The uniqueness of disaster logistics projects exists because of the uniqueness of each disaster. Two disasters are not exactly the same (Holguín-Veras et al., 2012b).

Complexity: practitioners frequently describe projects as simple or complex. This indicates a practical acceptance that complexity makes a difference to the management of projects. Definition of project's complexity consists of many varied interrelated parts (activities and resources), and a complicated, involved dimension (Baccarini, 1996). Several authors consider complexity as one of the four characteristics that make RO a more difficult problem to handle with regard to general business logistics. This expresses the need for delivering a significant and wide variety of supplies in a short period of time (Van Wassenhove, 2006; Pettit \& Beresford, 2009; Balcik et al., 2010). In addition, as many humanitarian organizations are involved in $\mathrm{RO}$, coordination and collaboration is difficult to achieve. Goldschmidt and Kumar (2016) affirms that humanitarian organizations have historically operated independently with the lack of cooperation and coordination often resulting in the failure of many of the RO.

Temporary nature: projects and their related activities have a defined beginning and end time. RO projects start their activities (start time) at the moment the disaster occurs and the operation ends when the affected people are restituted. The duration of the project depends on the region, the magnitude and type of disaster. In Colombia, the start and end time of RO activities are defined in actuation protocols. For example, according to SNPAD (2006a), the response activities of a SNND, may last a week, starting from the moment the disaster occurs. 
Uncertainty: projects are planned prior to execution; thus, they carry an important risk element. The uncertainty is evidenced in three of the four characteristics reported in the literature that makes RO a more difficult problem to handle with regard to general business logistics. First, authors such as Sheu (2007) and Vitoriano et al. (2010) considered that unexpected damages may be caused to infrastructure affected by a disaster, thus complicating the distribution of resources and rescue operations. Second, the information on the amount of resources required is quite limited as the demand of resources is unpredictable and changes with time. Third, the requirement of logistic resources during an emergency situation cannot be controlled directly by decision makers (Van Wassenhove, 2006; Pettit \& Beresford, 2009; Balcik et al., 2010).

Life cycle: the life cycle of a project consists of six phases: (1) a conceptual design phase where needs that justify project execution are identified. A (2) project definition phase in which the objectives of the project are defined along with the scope and strategy to achieve these objectives. The (3) planning phase, (4) scheduling phase, (5) implementation phase, and (6) termination phase are open to be defined by project managers. Regarding disaster management, the first four phases of a project: design, definition, planning and scheduling are activities developed during the mitigation or preparation phases of a disaster (see Table 1). Remain two phases of a project: implementation and termination are the RO itself, executed after the disaster occurs.

As shown above, RO are the activities to be planned, schedule and implemented as part of an humanitarian project for disasters attention. In this paper, we present the case of the planning phase of a project, with the intention to prepare the scheduling phase for the immediate response of a SNND project in Colombia.

\section{Table 1}

Disaster management stages according to different authors

\begin{tabular}{|c|c|c|c|c|c|}
\hline Authors & \multicolumn{5}{|c|}{ Disaster Stages } \\
\hline Van Wassenhove, (2006) & - & Preparation & \multirow{5}{*}{ 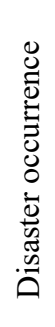 } & Post-disaste & \\
\hline Pettit and Beresford (2006) & - & Preparation & & Response & Reconstruction \\
\hline Altay and Green III (2006) & Mitigation & Preparation & & Response & Reconstruction \\
\hline Kovács and Spens (2007), (2009) & - & Preparation & & $\begin{array}{c}\text { Immediate } \\
\text { response }\end{array}$ & Reconstruction \\
\hline $\begin{array}{l}\text { Van Wasenhove (2006); Tomasini and Van } \\
\text { Wasenhove (2009) }\end{array}$ & Mitigation & Preparation & & Response & Rehabilitation \\
\hline
\end{tabular}

Source: Based on Moreno, 2012

\subsection{Relief Operations as a resource-constrained project}

The resource-constrained project scheduling problem (RCPSP) has been widely discussed in the literature, in both operations research and artificial intelligence, in order to develop algorithms and mathematical models that generate the best project schedules (Zhang et al., 2012; Lombardi \& Milano, 2012; Haouari et al., 2012).

It is well known for humanitarian authors that the RO of an SNND implies lack of resources specifically: supply, people, technology, transportation capacity, and money (Kovács \& Spens, 2009; Overstreet et al., 2011; Goldschmidt \& Kumar 2016; among others). Emergency or humanitarian supplies are of a very wide range (be they from formal or informal sources), which includes products and materials for use and consumption by the population, such as medicines, food products, household goods, clothing, etc., to those required by organizations to provide assistance, such as rescue equipment, building materials, tools, 
etc. (PAHO, 2000). The lack of resources to deal with convergence coupled with its usually large proportion of unsuitable aid (e.g., non- and low-priority donations) creates an important logistical challenge (Holguín-Veras et al., 2012b). Resource constrains in humanitarian context are also particularly useful to express the potential reduction of transport capacities after a disaster (Florez et al., 2015). In this study, we focus on the classical RCPSP that uses a finite number of renewable resources. The duration of each activity is assumed to be represented by a single, deterministic time, and activities cannot be interrupted once they have started (no preemption). Moreover, it presents precedence constraints strictly end-start type. From the classical RCPSP, multiple modes for projects implementation, and multiple projects that together fulfill a larger project, are two specific cases of RCPSP found in the literature. They are both described below and analyzed for a national RO situation.

\subsection{Relief Operations as a multi-mode project}

The multi-mode scheduling problem is an extension of the RCPSP model. Multi-mode projects are those in which the same activity can be executed using different types and amounts of resources, and therefore, they can be executed at different times. Projects with multiple modes are more realistic than those with a single mode, because in practice, resource variability is common during project implementation (Ju \& Chen, 2012). The difference between RCPSP and multi-mode resource-constraints project scheduling problem (MRCPSP) is that RCPSP has only one pair of activity duration-resource requirements to perform an activity, whereas in MRCPSP each activity can be, perform by selecting one out of several different combinations of activity duration-resource requirements. The various alternate combinations are call modes. Regarding RO projects, different modes exists because of the technical and technological evolution that may vary the types of resources and equipment to execute operations, and that are evident in changes of standards and protocols. The resources variety and the technical and technological differences exists not only among time, but also among the organizations involved in response operations; local, international, governmental, non-governmental, ONG's, third party logistics, and a big range of donors (Kovács and Spens, 2007). For example, in Colombia, at least 20 organizations are involved in national disaster response operations.

The variety and number of actors generate multiple projects that run simultaneously, as organizations present differences in nature, culture, size, area of specialization and mode of operation (Chandes \& Paché, 2010). These actors are geographically dispersed, have little or no communication between them, and an inadequate division of labor (Oloruntoba \& Gray, 2006) this makes their aid activities generate independent projects, which are executed on a common infrastructure, many times congesting it, a phenomenon known as convergence of materials, information and personnel (Holguín-Veras and Jaller, 2012).

\subsection{Relief Operations as a multi-project}

Multi-projects are those that together fulfill a larger project, its activities are independent from each other, but some resources are commonly used/shared among the subprojects (Geiger, 2017). The RO for national disasters can be considered a multi-project problem, with all activities being classified in groups based on a specific goal, in which each group or subproject fulfills a larger humanitarian attention project. When multiple projects are simultaneously executed, and their activities require common resources, a multi project board helps to coordinate activities, its resource allocation and the coordination of the different areas of the organizations involved. Different project management tools, like the ones proposed by the Project Management Institute (PMI) in its Guide to the Project Management Body of Knowledge (PMBOOK, 2004) can be used to allow visualization and quantification of scarce resources, distribute them avoiding conflicts between them and decreasing the duration of the different projects. 
According to Holguín-Veras et al. (2012a) the humanitarian logistics must deliver supplies to meet the needs of the response process which includes: food and water for the responders; equipment and supplies for medical teams, search and rescue, security forces; transportation, and construction equipment and fuel. The definition and coordination of those subprojects depends of the regional Government. For example, in the United States, the Federal Emergency Management Agency (FEMA) considers 15 subprojects related as emergency support functions, for responding disasters, and include: transportation; communications; public works and engineering; firefighting; emergency management; mass care, emergency assistance, housing, and human services; logistics management and resource support; public health and medical services; search and rescue; oil and hazardous materials response; agriculture and natural resources; energy; public safety and security; long-term community recovery; external affairs (FEMA, 2008). Two approaches have been used to board multiple projects, (see Fig. 3): (a) a multiproject (MP) approach, conserving a separate critical path per project, and (b) a single-project approach, using dummy activities and precedence arcs to combine the projects into a single mega-project and a single critical path.

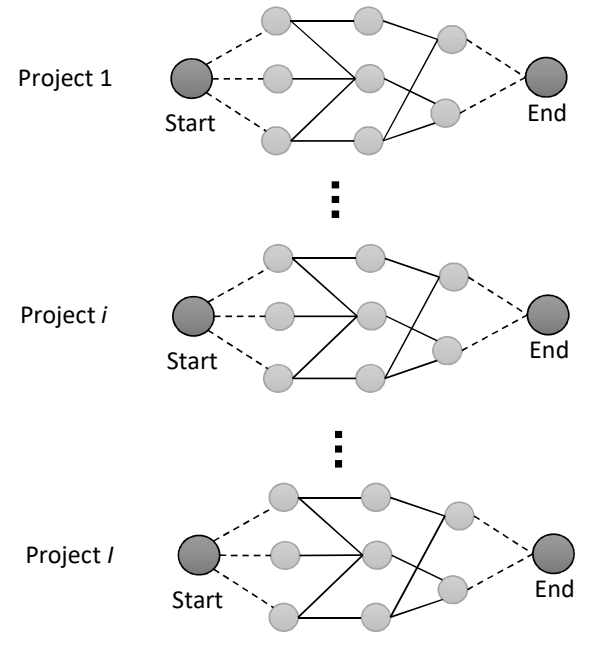

(a) Multiproject approach

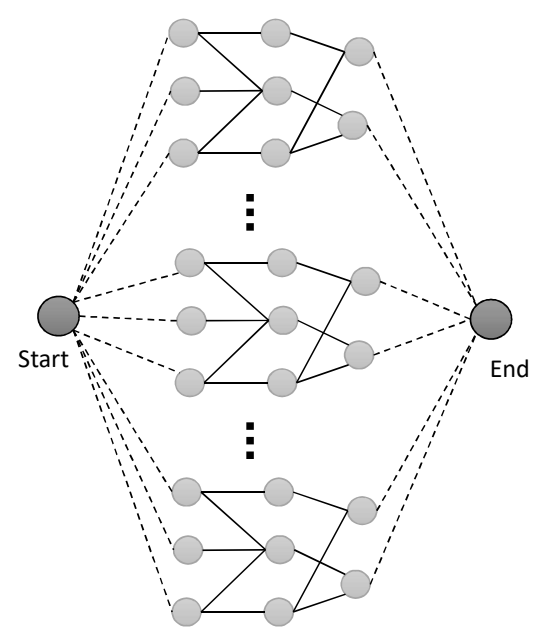

(b) Single-Project approach

Fig. 3. The two multi-project representation's approaches. Source: Ju and Chen, 2012

When dealing with national disaster attention, the multi-project is the most appropriate approach for the following reasons. As noted by Browning and Yassine (2010a), the single-project approach is less realistic, as it implicitly assumes equal delay penalties for all projects. Moreover, aggregating multiple projects yields very large problems and independent project analysis becomes difficult. Finally, because subprojects in response operations are commonly led by different organizations (FEMA, 2008), so each subproject has its own manager who is mainly interested in the individual project's descriptive characteristics. As manager organizations and support organizations may take part of different subprojects, resources among subprojects -such as staff, infrastructure, transport and communication equipment, etc.- are sheared (FEMA, 2008). Multi-project scheduling model, as a model that coordinates different subprojects activities, answers to one of the strongest challenges of humanitarian logistics: the coordination of logistical activities among organizations involved in response operations (Wilson et al., 2018; Kovács \& Spens, 2009; Holguín-Veras et al., 2012b). As noted before, so many humanitarian organizations are involved in response operations, so coordination and collaboration is difficult to achieve. Goldschmidt and Kumar (2016) affirms that humanitarian organizations have historically operated independently with the lack of cooperation and coordination often resulting in the failure of many of the RO. Multi-project scheduling model may give a global coordination support to the independent activities of different organizations involved in a national disaster response. 


\section{The case of Colombian RO as a multi-project}

\subsection{Origin of the Colombian RO system}

Since the flood caused by the activation of the Ruiz volcano in November 13, 1985, the Colombian government identified the need to create a system to prevent and coordinate disaster response and attention. Thus, it created the National System for Disaster Attention and Prevention (SNPAD, in its Spanish acronym). Then, in 2011 it identified the need to adopt a comprehensive approach toward disaster management (not only prevention and attention), and created the National Unit for Disaster Risk Management (UNGRD, in its Spanish acronym) (Colombian Republic, 2011; UNGRD, 2012).

\subsection{Structure of the Colombian RO system}

As a multi-project, Colombian system is organized into ten (10) subsystems (SNPAD, 2006a), based on the primary goal in emergency situations (see Fig. 4). Aid activities of each subsystem represent a single project. The ten subsystems or subprojects are classified as follows: (1) search and rescue, (2) health and sanitation, (3) feeding and lodging, (4) public services, (5) aid management, (6) telecommunications, (7) public order or security, (8) accessibility and transport, (9) habitat and housing, and (10) production. This structure and way of operating continues in force in 2018.

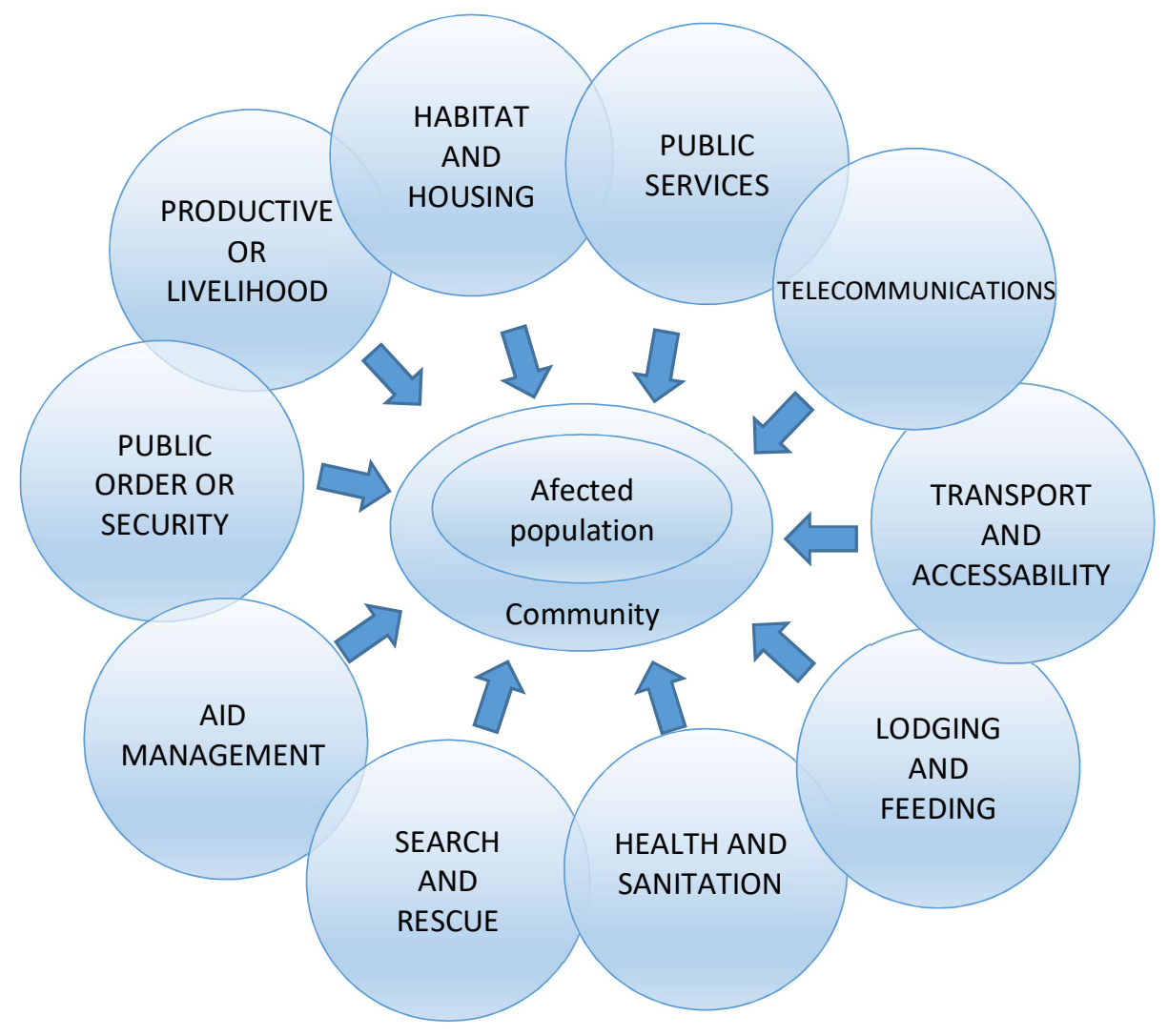

Fig. 4. Colombian post-disaster humanitarian system. Source: Based on Moreno, 2012

Each subsystem of Colombian System has a governing entity and a set of supporting organizations (see Table 2). As some organizations participate in more than one subproject, it reveals that among those subprojects, resources are sheared. Each subsystem has its own objective, and they all together fulfil the global RO objective. The UNGRD, is the Colombian organization in charge of the global multi-project coordination. 
Table 2

Ten subprojects of Colombian RO

\begin{tabular}{|c|c|c|}
\hline Subproject & Coordinating entity & Support entities \\
\hline Transport and accessibility & Ministry of Transport & $\begin{array}{l}\text { Civil Aeronautics of Colombia, INVIAS, DIMAR, INCO, } \\
\text { DGR, Road Police, Air Force, Navy. }\end{array}$ \\
\hline Lodging and feeding & Ministry of Social Protection & $\begin{array}{l}\text { Ministry of Education, Colombian Red Cross, Colombian } \\
\text { Civil Defense, National Police, Military Forces, SENA, } \\
\text { Ministry of Social Protection, DGR, Ministry of Agriculture. }\end{array}$ \\
\hline Search and rescue & Colombian Civil Defense & $\begin{array}{l}\text { Colombian Red Cross, Military Forces, National Fire System, } \\
\text { Ministry of Transport, Civil Aeronautics of Colombia, } \\
\text { Ministry of Social Protection, National Police, DGR. }\end{array}$ \\
\hline Habitat and housing & $\begin{array}{l}\text { Ministry of Environment, } \\
\text { Housing and Territorial } \\
\text { Planning - Housing } \\
\text { Directorate }\end{array}$ & $\begin{array}{l}\text { Compensation Offices, National Housing Fund, Agrarian } \\
\text { Bank, CREPAD, CLOPAD, Ministry of Agriculture. }\end{array}$ \\
\hline Aid management & Colombian Red Cross & $\begin{array}{l}\text { Ministry of Foreign Affairs, DGR, Colombian Civil Defense, } \\
\text { DIAN, Ministry of Education, Ministry of Social Protection, } \\
\text { National Police, National Disaster Fund, Attorney-general. }\end{array}$ \\
\hline Public order or security & $\begin{array}{l}\text { Ministry of the Interior and } \\
\text { Justice - Territorial Direction } \\
\text { and Public Order and Citizen } \\
\text { Coexistence }\end{array}$ & $\begin{array}{l}\text { Ministry of Defense-General Command of the Military } \\
\text { Forces, National Police, Ministry of the Interior and Justice, } \\
\text { General Public Prosecutor's Office, Penitentiary Guard, DGR }\end{array}$ \\
\hline Productive or livelihood & Ministry of Agriculture & $\begin{array}{l}\text { Ministry of Commerce, ACOPI, INCODER, ICA, Agrarian } \\
\text { Bank, FINAGRO, CORPOICA, SAC, FEDEGAN, FENAVI, } \\
\text { Supply Corporations, ANDI, Colombian Security Council, } \\
\text { Chamber of Commerce }\end{array}$ \\
\hline Health and sanation & Ministry of Social Protection & $\begin{array}{l}\text { Colombian Red Cross, Colombian Civil Defense, IPS, } \\
\text { General Public Prosecutor's Office, National Police, Military } \\
\text { Forces, ICBF, DGR. }\end{array}$ \\
\hline Public services & $\begin{array}{l}\text { Ministry of Mines and } \\
\text { Energy }\end{array}$ & $\begin{array}{l}\text { Ministry of Environment, Superintendent of Public Services, } \\
\text { Drinking Water Regulatory Commission, CREG, National } \\
\text { Police, Private businesses. }\end{array}$ \\
\hline Telecommunications & Ministry of Communications & $\begin{array}{l}\text { Operators, DGR, Ministry of Social Protection, Ministry of } \\
\text { Defence, Military Forces, National Police, Colombian Red } \\
\text { Cross, Civil Defense. }\end{array}$ \\
\hline \multicolumn{3}{|c|}{$\begin{array}{l}\text { INVIAS: National Institute of Roads. DIMAR: Maritime General Directorate. INCO: National Institute of Concessions. DGR: General Directorate of } \\
\text { Revenue. SENA: National Learning Service. CREPAD: Regional Committee for Disaster Prevention and Response. CLOPAD: Local Committee for Disaster } \\
\text { Prevention and Response. DIAN: National Tax and Customs Office. ACOPI: Colombian Association of Micro, Small and Medium Enterprises. INCODER: } \\
\text { Colombian institute of rural development. ICA: Colombian Agricultural Institute. FINAGRO: Fund for the financing of the agricultural sector. CORPOICA: } \\
\text { Colombian Corporation of Agricultural Research. SAC: Colombian Farmers' Association. FEDEGAN: Colombian Federation of ranchers. FENAVI: National } \\
\text { Poultry Federation. ANDI: National Association of Employers of Colombia. IPS: Health Services Institutions. ICBF: Colombian Institute of Family Welfare. } \\
\text { CREG: Energy and Gas Regulatory Commission. }\end{array}$} \\
\hline
\end{tabular}

Source: Based on SNPAD, 2006i

\subsection{Data gathering}

To identify Colombian subprojects activities, precedence constraints and resource requirements, data was collected from official documents concerning to action protocols for an SNND (SNPAD, 2006a, 2006b, 2006c, 2006d, 2006e, 2006f, 2006g, 2006h, 2006i), web site of coordinating entities, and by face-to-face semi structured interviews to experts. The interviews were conducted from January 2013 to June 2013. Based on Harrell and Bradley (2009), we first conducted a judgment sampling, selecting directive members from $100 \%$ of the coordinated entities and from the organization in charge of the global multiproject coordination, UNGRD. Then, we asked the selected sample to refer us to persons with the necessary knowledge of each specific subproject coordination. This final snowball sampling resulted in 
15 participants interviewed (4 members of coordinated entities, 3 members of support entities and 8 members of UNGRD), who cover $100 \%$ of the subprojects knowledge coordination.

We asked the interviewed to answer all questions based on their experiences (strategic level) the RO of a national earthquake of identical dimensions of the one occurred in Armenia, in 1999. We also asked them to answer according to the current technical and technological level, so that the current Colombian mode -and not 1999 technical and technological mode- (activities, resources required for each activity and duration of each activity) for the RO was defined. The interview presented three sections questionnaire (Appendix A) based on experience questions (Harrell and Bradley, 2009). The first section aimed to identify the objective of each subproject and the activities required to execute it, as well as the precedence constraints of activities. This first section resulted in the construction of a Work Breakdown Structure (WBS) and a basic precedence diagram for each subproject.

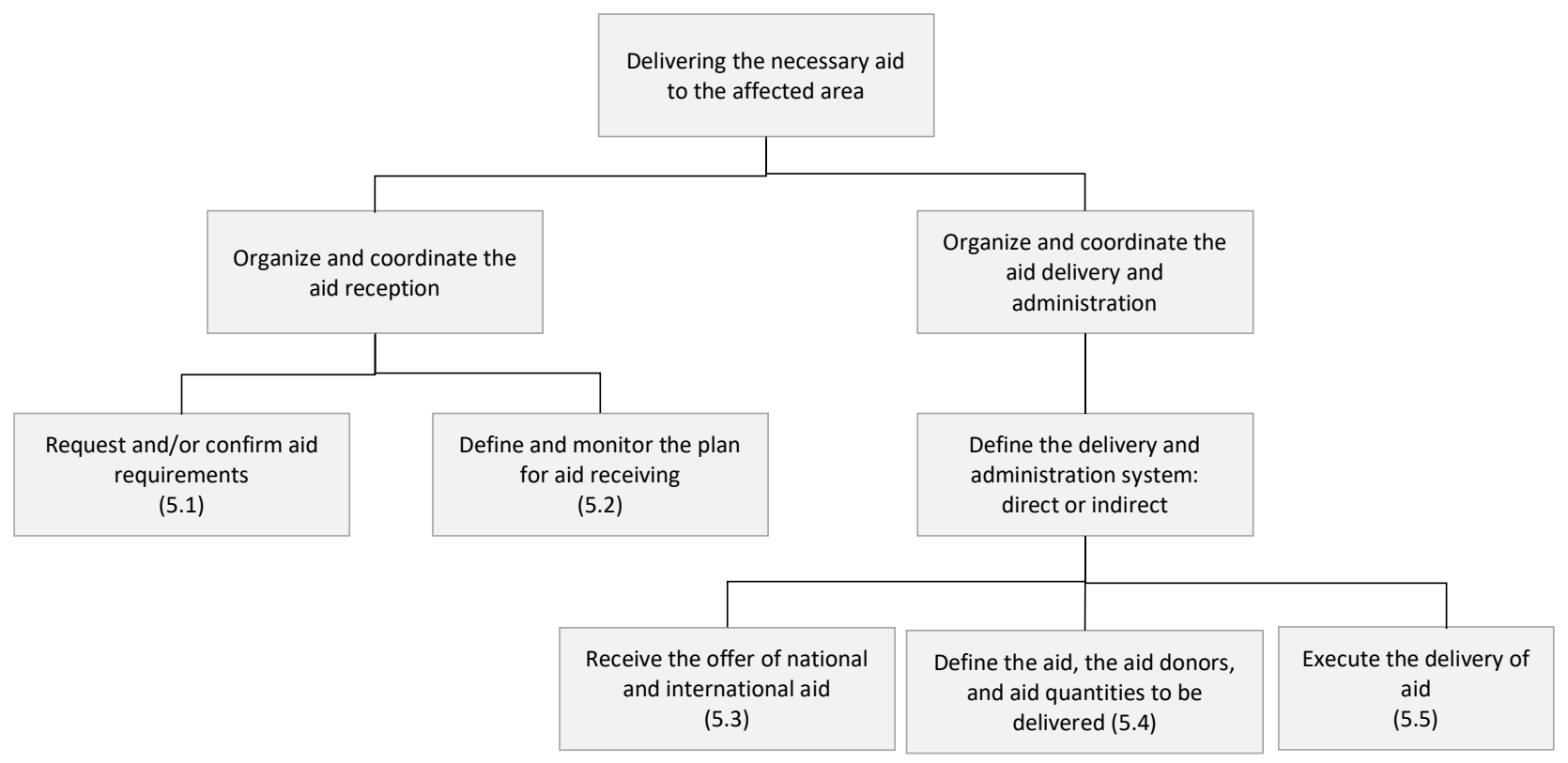

Fig. 5. WBS of Colombian Aid Management subproject

The second section aimed to identify the renewable resources needed for each task in each subproject, so it resulted in a resource matrix. Finally, the third section aimed to identify the estimation of duration of activities and the amount of each of the resources required for responding to a national earthquake. It resulted in a database, which integrates the WBS tasks with the time and resources needs of each activity. As a sample, in Fig. 5, Fig. 6 and Table 3 are shown respectively, the WBS, the precedence diagram, and the matrix of resources required for the Colombian Aid Management subproject, resulted from the interview to a UNGRD member.

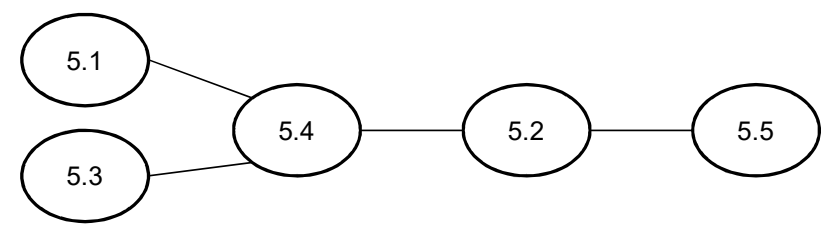

Fig. 6. Precedence diagram of Colombian Aid Management subproject 
Table 3

Resources matrix of Colombian Aid Management subproject

\begin{tabular}{|c|c|c|c|c|c|}
\hline \multicolumn{2}{|c|}{ NODE (Work package) } & \multirow{2}{*}{ RESPONSABLE } & \multirow{2}{*}{ RESOURCE } & \multirow{2}{*}{ QUANTITY } & \multirow{2}{*}{$\begin{array}{l}\text { RELATIVE } \\
\text { UNIT }\end{array}$} \\
\hline CODE & ACTIVITY & & & & \\
\hline \multirow{4}{*}{5.1} & \multirow{4}{*}{$\begin{array}{l}\text { Request and/or } \\
\text { confirm aid } \\
\text { requirements }\end{array}$} & \multirow{4}{*}{$\begin{array}{l}\text { General and operational } \\
\text { vice principal (Colombian } \\
\text { Civil Defense) }\end{array}$} & $\begin{array}{l}\text { General and operational vice principal } \\
\text { (Colombian Civil Defense) }\end{array}$ & 1 & Disaster \\
\hline & & & UNGRD* Professional & 10 & Disaster \\
\hline & & & Computers & 6 & Disaster \\
\hline & & & Radiotelephones & 6 & Disaster \\
\hline \multirow{5}{*}{5.2} & \multirow{5}{*}{$\begin{array}{l}\text { Define and } \\
\text { monitor the plan } \\
\text { for aid receiving }\end{array}$} & \multirow{2}{*}{$\begin{array}{l}\text { Director of National relief } \\
\text { (Red Cross) }\end{array}$} & $\begin{array}{l}\text { Director of national relief (Colombian } \\
\text { Red Cross) }\end{array}$ & 1 & Disaster \\
\hline & & & $\begin{array}{l}\text { Director of International Cooperation } \\
\text { (Ministry of Foreign Affairs) }\end{array}$ & 1 & Disaster \\
\hline & & \multirow{3}{*}{$\begin{array}{l}\text { Director of International } \\
\text { Cooperation (Ministry of } \\
\text { Foreign Affairs) }\end{array}$} & Municipal Public Professional & 1 & $\begin{array}{l}\text { Affected } \\
\text { Municipality }\end{array}$ \\
\hline & & & Department Public Professional & 1 & $\begin{array}{l}\text { Affected } \\
\text { Department }\end{array}$ \\
\hline & & & Computers & 10 & Disaster \\
\hline \multirow{5}{*}{5.3} & \multirow{5}{*}{$\begin{array}{l}\text { Receive the } \\
\text { offer of national } \\
\text { and international } \\
\text { aid }\end{array}$} & \multirow{2}{*}{$\begin{array}{l}\text { Director of National relief } \\
\text { (Colombian Red Cross) }\end{array}$} & $\begin{array}{l}\text { Director of national relief (Colombian } \\
\text { Red Cross) }\end{array}$ & 1 & Disaster \\
\hline & & & $\begin{array}{l}\text { Director of International Cooperation } \\
\text { (Ministry of Foreign Affairs) }\end{array}$ & 1 & Disaster \\
\hline & & \multirow{3}{*}{$\begin{array}{l}\text { Director of International } \\
\text { Cooperation (Ministry of } \\
\text { Foreign Affairs) }\end{array}$} & UNGRD* Professional & 10 & Disaster \\
\hline & & & Computers & 6 & Disaster \\
\hline & & & Radiotelephones & 6 & Disaster \\
\hline \multirow{5}{*}{5.4} & \multirow{5}{*}{$\begin{array}{l}\text { Define the aid, } \\
\text { the aid donors, } \\
\text { and aid } \\
\text { quantities to be } \\
\text { delivered }\end{array}$} & \multirow{2}{*}{$\begin{array}{l}\text { Director of National relief } \\
\text { (Colombian Red Cross) }\end{array}$} & $\begin{array}{l}\text { Director of national relief (Colombian } \\
\text { Red Cross) }\end{array}$ & 1 & Disaster \\
\hline & & & $\begin{array}{l}\text { Director of International Cooperation } \\
\text { (Ministry of Foreign Affairs) }\end{array}$ & 1 & Disaster \\
\hline & & \multirow{3}{*}{$\begin{array}{l}\text { Director of International } \\
\text { Cooperation (Ministry of } \\
\text { Foreign Affairs) }\end{array}$} & UNGRD* Professional & 10 & Disaster \\
\hline & & & Computers & 6 & Disaster \\
\hline & & & Radiotelephones & 6 & Disaster \\
\hline \multirow{9}{*}{5.5} & \multirow{9}{*}{$\begin{array}{l}\text { Execute the aid } \\
\text { delivery }\end{array}$} & \multirow{5}{*}{$\begin{array}{l}\text { Director of National relief } \\
\text { (Colombian Red Cross) }\end{array}$} & $\begin{array}{l}\text { Director of national relief (Colombian } \\
\text { Red Cross) }\end{array}$ & 1 & Disaster \\
\hline & & & $\begin{array}{l}\text { Director of International Cooperation } \\
\text { (Ministry of Foreign Affairs) }\end{array}$ & 1 & Disaster \\
\hline & & & UNGRD Professional & 6 & Disaster \\
\hline & & & Public Professional & 6 & Disaster \\
\hline & & & Drivers & 1 & Truck \\
\hline & & \multirow{4}{*}{$\begin{array}{l}\text { Director of International } \\
\text { Cooperation (Ministry of } \\
\text { Foreign Affairs) }\end{array}$} & Trucks & 1 & $\begin{array}{l}38 \text { tonnes of } \\
\text { aid to be } \\
\text { delivered }\end{array}$ \\
\hline & & & Radiotelephones & 6 & Disaster \\
\hline & & & Computers & 6 & Disaster \\
\hline & & & Volunteers & 5 & Truck \\
\hline
\end{tabular}

*UNGRD: National Unit for Disaster Risk Management (in its Spanish acronym)

\subsection{Colombian RO objective}

To study Colombian RO we considered a project with the objective of minimizing the makespan of a sudden, natural and national earthquake i.e., the minimization of deaths (Moreno, 2012). The time period considered is the response phase (one week since the disaster occurs, according to SNPAD, 2006a). The earthquake is the second type of sudden natural disasters in the world and has the highest occurrence possibility in Colombia (Moreno, 2012). 


\subsection{Characteristics of Colombian RO multi-project}

In order to understand the behavior of Colombian RO multi-project, we calculate its characteristics. Table 4 summarizes the characteristics of the project for the Colombian RO. Resource contention (MAUF) was not calculated, as resource distribution value $(A R L F)$ was sufficient to describe resource behavior ( $A R L F$ not near $\varnothing$ ). As shown in Table 4, projects with less than six activities have a low network complexity. Considering that an exclusive resource for one activity may not cause resource constrained conflicts, only shared resources among activities (or projects) were considered for calculating the $A R L F$ indicator.

\section{Table 4}

Colombian RO characteristics

\begin{tabular}{|c|c|c|c|c|c|c|c|c|}
\hline $\mathbf{N}^{\circ}$ & Subproject & $\begin{array}{l}\text { Activities } \\
\text { (n) }\end{array}$ & $\begin{array}{l}\text { Non- } \\
\text { reduntant } \\
\operatorname{arcs}\left(a^{\prime}\right)\end{array}$ & $\begin{array}{c}\text { Network } \\
\text { complexity } \\
(c)^{*}\end{array}$ & $\begin{array}{c}C \\
\text { Qualification }\end{array}$ & $\begin{array}{c}\text { Critical } \\
\text { path } \\
\text { duration } \\
\text { (hours) }\end{array}$ & $\begin{array}{c}\text { Resources } \\
\text { distribution } \\
(A R L F)^{* *}\end{array}$ & $\begin{array}{c}A R L F \\
\text { qualification }\end{array}$ \\
\hline 1 & Transport and accessibility & 13 & 13 & -0.033 & Low & 39 & -1690.176 & Negative \\
\hline 2 & Lodging and feeding & 11 & 9 & NA & Low & 22 & -2149.163 & Negative \\
\hline 3 & Search and rescue & 17 & 17 & -0.018 & Low & 15 & 257.731 & Possitive \\
\hline 4 & Habitat and housing & 3 & 1 & NA & Low & 9 & -29898.498 & Negative \\
\hline 5 & Aid management & 5 & 4 & NA & Low & 23 & 11.760 & Possitive \\
\hline 6 & Public order or security & 8 & 7 & -0.222 & Low & 7 & -2188.689 & Negative \\
\hline 7 & Productive or livelihood & 7 & 5 & NA & Low & 43.5 & -9.752 & Negative \\
\hline 8 & Health and sanation & 32 & 33 & 0.000 & Low & 117.25 & -4677.915 & Negative \\
\hline 9 & Public services & 17 & 21 & 0.053 & Low & 42.8 & -79.074 & Negative \\
\hline 10 & Telecommunications & 16 & 15 & -0.041 & Low & 120 & -5.622 & Negative \\
\hline
\end{tabular}

* Dummy activities are not considered to calculate $C_{l}$

** Based on scheduling each activity at its early start time (EST schedule)

As shown in Table 5, all of the Colombian RO projects have a low network complexity $(C \leq 0.14)$. The multi-project vector is surprising, given the complexity feature of RO described in section 2.1. Therefore, although RO are naturally complex, they can certainly be manageable by employing a multi-project management approach. Resource distribution for the multi-project Colombian case was calculated using Eq. (3).

$$
N A R L F=-33,69
$$

The Colombian NARLF result represents a back-loaded resources distribution. It is surprising because, as mentioned before, some authors affirmed that emergency situations require significant amounts of rescue materials that must be assigned and distributed in a short period of time, especially immediately after a disaster occurs. Hence, a front-loaded resource distribution was expected. This behavior may be a consequence of the fact that the project is design at a strategic level, so that at this level, resources needed are not of significant amounts. We may also consider that when a disaster occurs, diagnosis activities are executed to identify disaster damages. Then, according to the diagnosis stage, response activities are executed. Diagnosis activities require less resources than response activities, but the time duration required for completion of diagnosis activities may not always be lower than response activities. Thus, two observations can be provided for observing a back-loaded resource distribution: first, because of the current disaster response mode, the Colombian system has a prolonged diagnosis stage. Second, resources required in diagnosis activities is significantly different from resources required in response activities. Based on both this two observations, it is suggested to find ways to reduce the duration of the diagnosis stage. 


\section{Conclusions}

From a conceptual point of view, this paper present the relief operations (RO), responding to a SNND, by employing a project approach. Relief Operations can be addressed as a multi-mode resourceconstrained multi-project scheduling problem (MPRCPSP). This approach answers to one of the strongest challenges of humanitarian logistics: the coordination of logistical activities among organizations involved in response operations. Furthermore, it enable the use of project management tools (successful in other contexts) in order to find better response times and reduce mortality caused by natural disasters. The methodology used for the Colombian case can be extended to RO from other countries, other natural disasters (such as flood, mass movements, and windstorms), and other levels of decision making (tactical and operative). The methodology outputs can be used as a base for developing software and disaster response protocols that facilitate decision making for allocating and distribution of resources at a strategic level.

For the Colombian project case, RO presents a low network complexity and a back-loaded resources distribution. The low network complexity reveals the convenience to board Colombian RO as a MRCMPSP because it can certainly be a manageable project. It also suggests replicating, for future research, the methodology in other countries to evaluate if the convenience of boarding RO as a MRCMPSP may or may not be generalized. Because of the significant amounts of resources required immediately after a disaster occurs, a front-loaded resource distribution was expected. Instead, a backloaded resource distribution was observed, which suggests that the Colombian disaster phase of diagnosis, spend more time than desirable to meet the victim's needs. It is suggested that more efforts (project modes) should be taken to reduce time of the planning activities (preparation phase) of a national disaster in Colombia.

\section{Acknowledgment}

Authors truly express gratitude to undergraduate students of Engineering Faculty of Universidad de La Sabana, who supported the interview process. We also thank to the interviewee members of public and private Colombian entities, for their time and commitment. Finally we would like to thank Universidad de La Sabana and its sponsorship of research: Methodology for the allocation and localization of resources in humanitarian logistics systems in collaborative contexts, under uncertainty, through project dynamics and focused logistics.

\section{References}

Altay, N., \& Green, W. G., (2006). OR/MS research in disaster operations management. European Journal of Operational Research, 175(1), 475-493.

Baccarini, D. (1996). The concept of project complexity-a review. International Journal of Project Management, 14(4), 201-204.

Balcik, B., Beamon, B. M., Krejci, C. C., Muramatsu, K. M., \& Ramirez, M., (2010). Coordination in humanitarian relief chains: Practices, challenges and opportunities. International Journal of Production Economics, 126(1), 22-34.

Browning, T. R., \& Yassine, A. A. (2010a). Resource-constrained multi-project scheduling: Priority rule performance revisited. International Journal of Production Economics, 126(2), 212-228.

Browning, T. R., \& Yassine, A. A., (2010b). A random generator of resource-constrained multi-project network problems. Journal of Scheduling, 13(2), 143-161. 
Brucker, P., Drexl, A., Möhring, R., Neumann, K., and Pesch, E. (1999). Resource-constrained project scheduling: Notation, classification, models, and methods. European Journal of Operational Research, 112(1), 3-41.

Chandes, J., \& Paché G. (2010). Strategizing humanitarian logistics: the challenge of collective action. Problems and Perspectives in Management, 8(1)

Chang, Y., Wilkinson, S., Potangaroa, R., \& Seville, E. (2012). Managing resources in disaster recovery projects. Engineering. Construction and Architectural Management, 10, 557-580.

Demeulemeester, E., \& Herroelen, W. (2002). Scope and Relevance of Project scheduling. Project Scheduling, a Research Handbook. Kluwer Academic Publisher: New York, Boston, Dordrecht, London, Moscow.

Dikmen, N., \& Elias-Ozkan, S. T. (2016). Housing after disaster: A post occupancy evaluation of a reconstruction project. International Journal of Disaster Risk Reduction, 19, 167-178.

Dufour, É., Laporte, G., Paquette, J., \& Rancourt, M. Ė. (2018). Logistics service network design for humanitarian response in East Africa. Omega, 74, 1-14.

D'Haene, C., Verlinde, S., \& Macharis, C. (2015). Measuring while moving (humanitarian supply chain performance measurement-status of research and current practice). Journal of Humanitarian Logistics and Supply Chain Management, 5(2), 146-161.

Elnashai, A. S., Gencturk, B., Kwon, O.-S., Hashash, Y. M. A., Kim, S. J., Jeong, S.-H., and Dukes, J., (2012). The Maule (Chile) earthquake of February 27, 2010: Development of hazard, site specific ground motions and back-analysis of structures. Soil Dynamics and Earthquake Engineering, 42 (January 2011), pp. 229-245.

FEMA, (2008). Emergency support function Annexes: Introduction. Retrieved on August 4, 2015 from: https://www.fema.gov/media-library-data/20130726-1825-25045-

0604/emergency_support_function_annexes_introduction_2008_.pdf.

Ferrer, J. M., Ortuño, M. T., \& Tirado, G. (2016). A GRASP metaheuristic for humanitarian aid distribution. Journal of Heuristics, 22(1), 55-87.

Florez, J. V., Lauras, M., Okongwu, U., \& Dupont, L. (2015). A decision support system for robust humanitarian facility location. Engineering Applications of Artificial Intelligence, 46, 326-335.

Gacasan, E. M. P., \& Wiggins, M. W. (2017). Sensemaking through cue utilisation in disaster recovery project management. International Journal of Project Management, 35(5), 818-826.

Geiger, M. J. (2017). A multi-threaded local search algorithm and computer implementation for the multi-mode, resource-constrained multi-project scheduling problem. European Journal of Operational Research, 256, 729-741.

Goldschmidt, K. H., \& Kumar, S. (2016). Humanitarian operations and crisis/disaster management: A retrospective review of the literature and framework for development. International Journal of Disaster Risk Reduction, 20, 1-13.

Guanxiang, Z., Meng, Z., Zhiyong, Z., \& Guihai, L. (2010). An Evaluation Model for Emergency Logistics System. In Management and Service Science (MASS), 2010 International Conference on (pp. 1-4). IEEE.

Habibi, F., Barzinpour, F., \& Sadjadi, S. (2018). Resource-constrained project scheduling problem: review of past and recent developments. Journal of Project Management, 3(2), 55-88.

Haiti, Government, (2010), Plan de Acción para la Recuperación y el Desarrollo de Haití. Retrieved on September 8, 2012 at: http://whc.unesco.org/uploads/activities/documents/activity-651-7.pdf.

Haouari, M., Kooli, A., \& Néron, E., (2012). Enhanced energetic reasoning-based lower bounds for the resource constrained project scheduling problem. Computers and Operations Research, 39(5), 11871194.

Harrell, M. C., \& Bradley, M. A. (2009). Data collection methods. Semi-structured interviews and focus groups. Rand National Defense Research Institute, Santa Monica, California. Retrieved on February 12, 2013 at: http://www.dtic.mil/dtic/tr/fulltext/u2/a512853.pdf.

He, Q., Luo, L., Hu, Y., \& Chan, A.P.C., (2015), Measuring the complexity of mega construction projects in China-A fuzzy analytic network process analysis. International Journal of Project Management, 33(3), 549-563. 
Holguín-Veras, J., \& Jaller, M. (2012). Immediate resource requirements after hurricane Katrina. Natural Hazards Review, 13(2), 117-131.

Holguín-Veras, J., Jaller, M. Van Wassenhove, L. N., Pérez, N., \& Wachtendorf, T. (2012a). On the unique features of post-disaster humanitarian logistics. Journal of Operations Management, 30 (7-8), 494-506.

Holguín-Veras, J., Wachtendorf, T., Jaller, M., \& Jefferson, T. (2012b). Logistics and the Management of Critical Supplies Following Catastrophes. In R. Bissell (editor), Preparedness and Response for Catastrophic Disasters (pp. 131-150). Uniter States: Taylor and Francis Group.

ISO (1990). International Standard ISO/CD 8402-1 Quality Concepts and Terminology Part One: Generic Terms and Definitions", International Organization for Standardization, December.

Ju, C., \& Chen, T. (2012). Simplifying multiproject scheduling problem based on design structure matrix and its solution by an improved aiNet algorithm. Discrete Dynamics in Nature and Society, 2012.

Kalkman, J. P., \& de Waard, E. J. (2017). Inter-organizational disaster management projects: Finding the middle way between trust and control. International Journal of Project Management, 35(5), 889-899.

Kim, K. N., \& Choi, J. H., (2013). Breaking the vicious cycle of flood disasters: Goals of project management in post-disaster rebuild projects. International Journal of Project Management, 31 (2013), 147-160.

Kovács, G., \& Spens, K. M. (2007). Humanitarian logistics in disaster relief operations. International Journal of Physical Distribution and Logistics Management, 37(2), 99-114.

Kovács, G., \& Spens, K. M. (2009). Identifying challenges in humanitarian logistics. International Journal of Physical Distribution and Logistics Management, 39(6), 506-528.

Lombardi, M., \& Milano, M. (2012). A min-flow algorithm for Minimal Critical Set detection in Resource Constrained Project Scheduling. Artificial Intelligence, 182-183, 58-67.

Lin, Y., Kelemen, M., \& Kiyomiya, T. (2016). The role of community leadership in disaster recovery projects: Tsunami lessons from Japan. International Journal of Project Management, 35(5), 913-924.

Lin Moe, T., Gehbauer, F., Senitz, S., \& Mueller, M. (2007). Balanced scorecard for natural disaster management projects. Disaster Prevention and Management: An International Journal, 16(5), 785806.

Lu, Y., Luo, L., Wang, H., Le, Y., \& Shi, Q. (2015). Measurement model of project complexity for largescale projects from task and organization perspective. International Journal of Project Management, 33(3), 610-622.

Makepeace, D., Tatham, P., \& Wu, Y. (2017). Internal integration in humanitarian supply chain management: Perspectives at the logistics-programmes interface. Journal of Humanitarian Logistics and Supply Chain Management, 7(1), 26-56.

Martinelli, R. J., \& Milosevic, D. Z. (2016). Schedule Development. In Project management toolbox: tools and techniques for the practicing project manager (pp. 171-222). John Wiley and Sons.

Mojtahedi, M., \& Oo, B. L. (2017). The impact of stakeholder attributes on performance of disaster recovery projects: The case of transport infrastructure. International Journal of Project Management, $35(5), 841-852$.

Moreno, K. V. (2012). Análisis de la relación entre estrategias de gestión logística humanitaria y el tiempo de respuesta en la atención de desastres, por medio de la metodología integral y dinámica. Universidad de La Sabana, Master Thesis, Chía, Colombia.

Nappi, M. M. L., \& Souza, J. C. (2015). Disaster management: hierarchical structuring criteria for selection and location of temporary shelters. Natural Hazards, 75(3), 2421-2436.

Oloruntoba, R., \& Gray, R. (2006). Humanitarian aid: an agile supply chain?. Supply Chain Management: An International Journal, 11(2), 115-120.

Ophiyandri, T., Amaratunga, D., Pathirage, C., \& Keraminiyage, K. (2013). Critical success factors for community-based post-disaster housing reconstruction projects in the pre-construction stage in Indonesia. International Journal of Disaster Resilience in the Built Environment, 10, 236-249

Overstreet, R. E., Hall, D., Hanna, J. B., \& Kelly Rainer Jr, R. (2011). Research in humanitarian logistics. Journal of Humanitarian Logistics and Supply Chain Management, 1(2), 114-131. 
PAHO- Pan American Health Organization (2000). Manual for the logistical management of humanitarian supplies. Retrieved from http:/cidbimena.desastres.hn/docum/ops/libros/manejologistico.pdf, in January of 2013

Patanakul, P., Iewwongcharoen, B., \& Milosevic, D. (2010). An empirical study on the use of project management tools and techniques across project life-cycle and their impact on project success. Journal of General Management, 35(3), 41-66.

PMBOOK Guide. (2004). A Guide to the Project Management Body of Knowledge. Third Edition. Four Campus Boulevard. Newtown Square, Pennsylvania. USA

PMI (2004). A guide to the project management body of knowledge. In Project Management Institute (Vol. 3).

Republic of Colombia, (2011). Decree 4147. Retrieved on September 22, 2012 at: http://wsp.presidencia.gov.co/Normativa/Decretos/2011/Documents/Noviembre/03/dec4147031120 11.pdf.

Pettit, S., \& Beresford, A., (2009). Critical success factors in the context of humanitarian aid supply chains. International Journal of Physical Distribution and Logistics Management, 39(6), 450-468.

Ransikarbum, K., \& Mason, S.J., (2014). Multiple-objective analysis of integrated relief supply and network restoration in humanitarian logistics operations. International Journal of Production Research, 54(1), 49-68.

Sadiqi, Z., Trigunarsyah, B., and Coffey, V. (2016). A framework for community participation in postdisaster housing reconstruction projects: A case of Afghanistan. International Journal of Project Management, 35(5), 900-912.

Sahebjamnia, N., Torabi, S. A., \& Mansouri, S. A. (2017). A hybrid decision support system for managing humanitarian relief chains. Decision Support Systems, 95, 12-26.

San Cristobal, J. R., (2015). Management Science, Operations Research and Project Management: Modelling, Evaluation, Scheduling, Monitoring (pp. 1-11). Routledge, NY, USA.

San Cristóbal, J. R. (2017). Complexity in Project Management. Procedia Computer Science, 121, 762 766.

Sheu, J.-B. (2007). An emergency logistics distribution approach for quick response to urgent relief demand in disasters. Transportation Research Part E, 43(6), 687-709.

SNPAD, Sistema Nacional para la Prevención y Atención de Desastres, (2006a). Guía de actuación y protocolos de alto Gobierno en caso de un desastre súbito de cobertura Nacional. Documento General, Retrieved on November 24, 2012. at: http://www.gestiondelriesgo.gov.co/snigrd/pagina.aspx?id=91.

SNPAD, Sistema Nacional para la Prevención y Atención de Desastres, (2006b). Protocolo de actuación del Presidente de la República en Caso de un desastre súbito de Cobertura Nacional, Retrieved on November 24, 2012. at: http://www.gestiondelriesgo.gov.co/snigrd/archivos/documentos/PROTOCOLOS/Protocolo\%20Pre sidente $\% 20 \mathrm{de} \% 201 \mathrm{a} \% 20$ Republica.pdf.

SNPAD, Sistema Nacional para la Prevención y Atención de Desastres, (2006c). Protocolo de actuación del Ministro del Interior y de Justicia en Caso de un desastre súbito de Cobertura Nacional, Retrieved on November 24, 2012. at:

http://www.gestiondelriesgo.gov.co/snigrd/archivos/documentos/PROTOCOLOS/Protocolo\%20Min istro\%20del \%20Interior.pdf

SNPAD, Sistema Nacional para la Prevención y Atención de Desastres, (2006d). Protocolo de actuación del Director de prevención y atención de desastres en caso de un desastre súbito de cobertura Nacional, Retrieved on November 24, 2012. at: http://www.gestiondelriesgo.gov.co/snigrd/archivos/documentos/PROTOCOLOS/Protocolo\%20Dir ector $\% 20$ de $\% 20$ PAD.pdf

SNPAD, Sistema Nacional para la Prevención y Atención de Desastres, (2006e). Protocolo de actuación de los Ministros del despacho en caso de un desastre súbito de cobertura Nacional, Retrieved on November 24, 2012. at: 
http://www.gestiondelriesgo.gov.co/snigrd/archivos/documentos/PROTOCOLOS/Protocolo\%20Min istros $\% 20 \mathrm{del} \% 20$ Despacho.pdf.

SNPAD, Sistema Nacional para la Prevención y Atención de Desastres, (2006f). Protocolo de actuación del comandante de las Fuerzas Militares y el Director de la Policía en caso de un desastre súbito de cobertura Nacional, Retrieved on November 24, 2012. at:

http://www.gestiondelriesgo.gov.co/snigrd/archivos/documentos/PROTOCOLOS/Protocolo\%20Fuerza s\%20Militares $\% 20 \mathrm{y} \% 20$ Policia.pdf.

SNPAD, Sistema Nacional para la Prevención y Atención de Desastres, (2006g). Protocolo de actuación del Procurador y Fiscal General de la Nación en caso de un desastre súbito de cobertura Nacional, Retrieved on November 24, 2012. at:

http://www.gestiondelriesgo.gov.co/snigrd/archivos/documentos/PROTOCOLOS/Protocolo\%20Procur ador $\% 20 \mathrm{y} \% 20$ Fiscal.pdf

SNPAD, Sistema Nacional para la Prevención y Atención de Desastres, (2006h). Protocolo de actuación de los medios masivos de información pública Nacional en caso de un desastre súbito de cobertura Nacional, Retrieved on November 24, 2012. at:

http://www.gestiondelriesgo.gov.co/snigrd/archivos/documentos/PROTOCOLOS/Protocolo\%20Medio s\%20de\%20Comunicacion.pdf.

SNPAD, Sistema Nacional para la Prevención y Atención de Desastres, (2006i). Relaciones entre autoridades territoriales en caso de un desastre súbito de cobertura Nacional, Retrieved on November 24, 2012. at:

http://www.gestiondelriesgo.gov.co/snigrd/archivos/documentos/PROTOCOLOS/08\%20Protocolo\%20 Autoridades\%20Territoriales.pdf.

UNGRD, Unidad Nacional para la Gestión del Riesgo de Desastres (2012). available at: http://portal.gestiondelriesgo.gov.co/, accessed on: November 8, 2012.

Vahanvati, M., \& Mulligan, M. (2017). A new model for effective post-disaster housing reconstruction: Lessons from Gujarat and Bihar in India. International Journal of Project Management, 35(5), 802817.

Van Wassenhove, L. N. (2006). Humanitarian aid logistics: supply chain management in high gear. Journal of the Operational Research Society, 57(5), 475-489

Van Wassenhove, L. N., \& Pedraza Martinez, A. J., (2012). Using OR to adapt supply chain management best practices to humanitarian logistics. International Transactions in Operational Research, 19(1-2), 307-322.

Vitoriano, B., Ortuño, M. T., Tirado, G., \& Montero, J., (2010). A multi-criteria optimization model for humanitarian aid distribution. Journal of Global Optimization, 51(2), 189-208.

Wilson, M. M., Tatham, P., Payne, J., L'Hermitte, C., \& Shapland, M. (2018). Best practice relief supply for emergency services in a developed economy: Evidence from Queensland Australia. Journal of Humanitarian Logistics and Supply Chain Management, 8(1), 107-132.

Yan, L., Jinsong, B., Xiaofeng, H., \& Ye, J. (2009). A heuristic project scheduling approach for quick response to maritime disaster rescue. International Journal of Project Management, 27(6), 620-628.

Zhang, L., Zou, X., \& Chen, X., (2012). Resource-constrained Scheduling in Repetitive Projects. International Journal on Advances in Information Sciences and Service Sciences, 4(14), 287-294.

Zheng, Y., Chen, S., \& Ling, H., (2015). Evolutionary optimization for disaster relief operations: A survey. Applied Soft Computing, 27, 553-566.

Appendix A. Interview questionnaire (original questionnaire was created and applied in Spanish)

Thank you for participating in our study about Colombian relief operations for an earthquake attention. Your response will be use only for academic purposes. 
Please answer all questions visualizing that you are attending a sudden and national earthquake of identical dimensions of the one occurred in Armenia, in 1999. Consider also, the current technical and technological conditions of Colombian system and not the 1999's conditions.

\section{Section 1}

1. Since you are a member of the coordinating group of the (mention here the indicated subsystem) area, please tell me what is the objective of this area?

2. When dealing with a national, sudden earthquake, what activities have to be done by (mention here the indicated subsystem) area for immediate response (during the first week)?

3. Does the activities have to be executed with specific precedence order? If so, How is that order?

\section{Section 2}

1. Please let me know which are the renewable resources needed in each of the activities you just mention?

2. How much quantity is needed of each resource in each activity?

Note: Renewable resources are those that are not consumed during the execution of an activity, so that when the activity ends, the resource remains available to be use in another activity. Some examples are manpower, machines and equipment.

\section{Section 3}

How much time is needed to execute each of the activities with those quantity of resources needed?

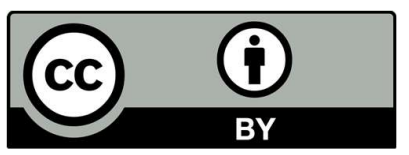

(C) 2019 by the authors; licensee Growing Science, Canada. This is an open access article distributed under the terms and conditions of the Creative Commons Attribution (CCBY) license (http://creativecommons.org/licenses/by/4.0/). 